\section{Creationism row forces out UK educator}

The director of education at Britain's Royal Society has been forced to resign after a massive outcry in the wake of widespread misreporting of comments he made about creationism in the classroom.

Michael Reiss, a professor at London's Institute of Education and an ordained minister in the Church of England, made the remarks at the British Association for the Advancement of Science's annual Festival of Science on 11 September in Liverpool. Three Nobel-prizewinning society fellows wrote to the society's president, Martin Rees, saying that they were "greatly concerned" at media reports of Reiss's talk. They are Richard Roberts, chief scientific officer of New England BioLabs in Beverly, Massachusetts; Harold Kroto of Florida State University in Tallahassee; and John Sulston of the University of Manchester, UK.

The Royal Society initially insisted that Reiss had been misrepresented and that his views do not differ from the society's position that "creationism has no scientific basis and should not be part of the science curriculum". After the letter of complaint and with the reported statements continuing to receive press coverage, including hostile opinion pieces, the society announced Reiss's departure on 16 September. See Editorial, page 431, and http://tinyurl.com/ 4zluv 9 for a longer version of this story.

\section{Anthrax enquiry to undergo independent review}

On the request of the Federal Bureau of Investigation, experts convened by the US National Academy of Sciences will review the FBI's scientific evidence against bioweapons researcher Bruce Ivins, who committed suicide earlier this year, in the anthrax bioterrorist attacks of 2001.

The scope and timeline have not yet been defined, but the assessment will exclude the 60 or so experts who consulted with the FBI on the case. Bureau director Robert Mueller

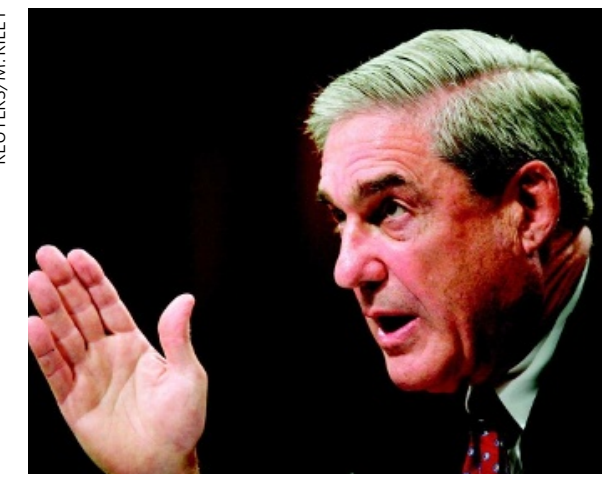

FBI director Robert Mueller.

\title{
Arctic ice shrinks less this year than last
}
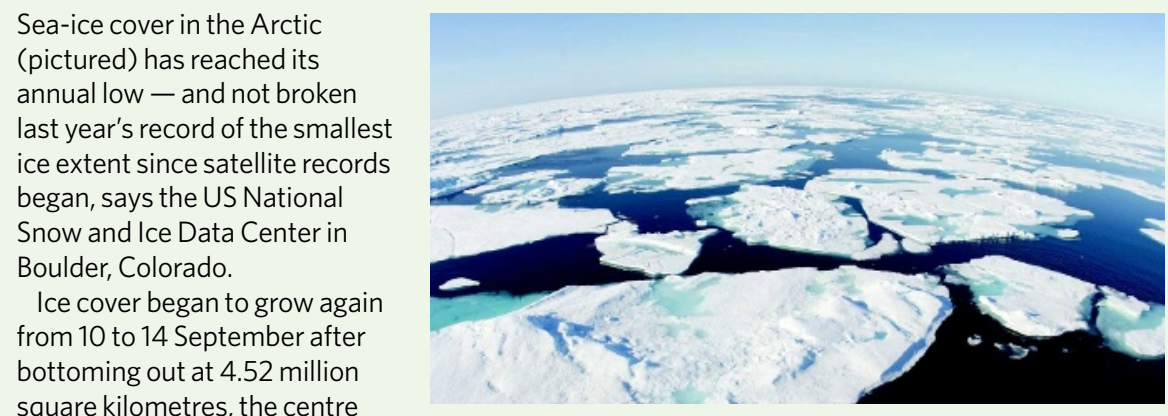
square kilometres, the centre

says. That's $9.4 \%$ more ice than last summer's minimum. Contributing factors include the fact that there were fewer warm days in the Arctic region this year than last, and also that winds blew in different directions instead of packing the ice together into a small area.

The International Arctic Research Center in Fairbanks, Alaska, also recorded a minimum last week: 4.71 million square kilometres on 9 September.

revealed the planned evaluation in testimony before judiciary committees of the Senate and House of Representatives last week.

Several lawmakers have expressed doubts about the FBI's case, questioning how the bureau eliminated all other possible suspects, and why it took so long to zero in on Ivins, a researcher at the US Army Medical Research Institute of Infectious Diseases in Fort Detrick, Maryland. Senator Patrick Leahy (Democrat, Vermont), a target in the mailings of deadly spores, said he believes the attacks were not a one-man job.

Mueller responded that the FBI had followed every lead; the case is expected to last for several months.

\section{Researcher punished for misconduct wins NSF grant}

Days after being sanctioned for research misconduct, bubble-fusion researcher Rusi Taleyarkhan was back in business - with a \$185,000 grant from the US National Science Foundation (NSF).

According to information on the foundation's website, Taleyarkhan, who is at Purdue University in West Lafayette, Indiana, has been contracted to work with students to develop a prototype particle detector based on the effect of radioactive particles on stressed fluids. Taleyarkhan's bubble-fusion experiments also involved the use of radioactive particles to seed bubbles in fluids.

In July, Taleyarkhan was found guilty of two charges of falsification and on 27 August Purdue banned him from having graduate students for three years, and withdrew his named professorship.

But the university apparently failed to notify NSF programme manager Rajinder Khosla, who confirms that Taleyarkhan's grant began on 15 September. Khosla says that he was not aware of the controversy, and plans to review the situation.

\section{Australian clinic gets permit to clone stem cells}

The in vitro fertilization clinic Sydney IVF has received Australia's first licence to conduct therapeutic cloning. The centre's team will be one of a handful of groups worldwide trying to achieve the feat.

In therapeutic cloning, also known as somatic-cell nuclear transfer, DNA from a patient's cell is introduced into an unfertilized egg. When the egg develops into an embryo, scientists extract stem cells and try to create an embryonic-stem-cell line that is a genetic match of the patient.

The licence provides for use of 7,200 human eggs over the next 3 years. Most other groups that have tried and failed have had only 20-30 eggs. Julia Schaft, who will lead the group, says it should be able to use at least 3,500 "clinically unsuitable" eggs from the 20,000 total the clinic collects each year.

\section{Agency drops disputed chelation study}

A controversial trial of chelation therapy for autism (see Nature 454, 259; 2008) has been scrapped by the US National Institute of Mental Health, which says its resources are better directed elsewhere.

The study was first proposed in 2006, but was referred for further ethics review after a 2007 publication reported that chelating agents could cause cognitive problems in rats. Critics charged that the study would needlessly expose children with autism to risk for no medical gain.

The American Academy of Pediatrics has recommended that the treatment be reserved for children with serious heavy-metal poisoning. Still, it is in broad underground use by parents of children with autism, many of whom believe the disease is due to mercury in childhood vaccinations. 